\title{
Distribution of aquatic macrophytes along depth gradients in Lajeado Reservoir, Tocantins River, Brazil
}

\author{
Distribuição de macrófitas aquáticas em gradientes de profundidade no reservatório
} de Lajeado, rio Tocantins, Brasil

Ester Vieira Noleto $^{1}$ (D), Marcus Vinícius Moreira Barbosa ${ }^{2}$ (D) and Fernando Mayer Pelicice ${ }^{1 *}$ (D)

${ }^{1}$ Núcleo de Estudos Ambientais, Universidade Federal do Tocantins - UFT, Rua 3, Quadra 17, Jardim dos Ipês, CEP 77500-000, Porto Nacional, TO, Brasil

${ }^{2}$ Programa de Pós-graduação em Biodiversidade e Biotecnologia da Rede Bionorte, Universidade Federal do Tocantins - UFT, Quadra 109, Norte, Av. NS-15, Plano Diretor Norte, CEP 77001-090, Palmas, TO, Brasil

*e-mail: fmpelicice@gmail.com

Cite as: Noleto, E.V., Barbosa, M.V.M. and Pelicice, F.M. Distribution of aquatic macrophytes along depth gradients in Lajeado Reservoir, Tocantins River, Brazil. Acta Limnologica Brasiliensia, 2019, vol. 31 , e6.

Abstract: Aim: The present study investigated the diversity of aquatic macrophytes in the littoral zone of Lajeado Reservoir, Tocantins River. We characterized spatial variations in species richness, composition and abundance along depth gradients. Methods: Macrophyte sampling occurred th the end of the dry season (September and October 2014) in four sites of the reservoir. We established transects perpendicular to the shoreline, each $25 \mathrm{~m}$ long, divided in 3 sections (plots of $5 \times 5 \mathrm{~m}$ ). Results: In total, we recorded 18 taxa of aquatic macrophytes, belonging to nine families and four life forms. Najas microcarpa, Echinodorus tenellus. and Chara sp. were the more frequent and abundant taxa. Considering depth gradients, we recorded 18 taxa in the section closer to the shoreline, 13 in the middle section and 10 in the section more distant to the shoreline. Submerged and emergent species were more frequent and abundant, especially in the section close to the shoreline; epiphytes and free-floating species were rare. Plot species richness (total, emergent and submerged) decreased along the gradient, and a Non-Metric Multidimensional Scaling (NMDS) revealed that the plot close to the shoreline had different composition when compared to adjacent sections. Individual species showed particular behaviors, but most tended to decline in abundance and occurrence along the gradient. Conclusions: The present study revealed that small-scale environmental gradients affect the distribution of aquatic plants in Lajeado Reservoir, with greater diversity in habitats close to the shoreline.

Keywords: aquatic plants; diversity; impoundment; littoral zone; microscale.

Resumo: Objetivo: O presente estudo investigou a diversidade de macrófitas aquáticas na zona litorânea do reservatório de Lajeado, rio Tocantins. O objetivo principal foi caracterizar variaçôes espaciais na riqueza de espécies, composição e abundância em gradientes de profundidade. Métodos: A amostragem de macrófitas ocorreu no final do período de estiagem (setembro e outubro de 2014) em quatro locais do reservatório. Estabelecemos transectos perpendiculares à margem, com $25 \mathrm{~m}$ de comprimento, divididos em 3 seçóes (plots de 5 x 5m). Resultados: No total, registramos 18 táxons de macrófitas aquáticas, pertencentes a nove famílias e quatro formas de vida. Os táxons mais frequentes e abundantes foram Najas microcarpa, Echinodorus tenellus e Chara sp. Considerando o gradiente de profundidade, registramos 18 táxons na seçấo mais próxima à margem, 13 na seção intermediária 
e 10 na seção mais distante da margem. Plantas submersas e emergentes foram mais frequentes e abundantes nas seçóes próximas à margem; plantas epífitas e livre flutuantes foram raras. A riqueza nos plots (total, emergente e submersa) declinou ao longo do gradiente, e uma Análise de Escalonamento não-Métrico (NMDS) revelou que os plots próximos à margem apresentaram composição de espécies diferenciada. As espécies apresentaram comportamentos particulares, mas a maioria teve a abundância e frequência reduzidas ao longo do gradiente. Conclusóes: $\mathrm{O}$ presente estudo revelou que gradientes ambientais em pequena escala afetam a distribuição das plantas aquáticas no reservatório de Lajeado, sendo a diversidade maior em habitats próximos às margens.

Palavras-chave: plantas aquáticas; diversidade; represamento; zona litorânea; microescala.

\section{Introduction}

Reservoirs are artificial ecosystems created by the impoundment of rivers, a human activity intended for several purposes, such as water storage, hydroelectricity and flood control (Tundisi \& Matsumura-Tundisi, 2003; Agostinho et al., 2007). Reservoirs cause significant shifts in the structure and functioning of fluvial ecosystems, changing the flow regime, depth, substrate and water quality (Poff et al., 1997; Agostinho et al., 2007). Such ecosystem shift affects biodiversity patterns, including species replacement, population decline/increase, and changes in spatial-temporal distribution (Agostinho et al., 2008).

Impoundments favor aquatic macrophyte development. It is common the development of dense and extensive macrophyte stands in shallow littoral habitats (e.g., Bini et al., 1999; Galo et al., 2002). These plants present predictable responses to physical-chemical factors (Murphy, 2000; Lacoul \& Freedman, 2006; Solimini et al., 2006), and reservoirs create ideal conditions for different life forms, e.g. emergent, submerged and floating plants (Thomaz \& Bini, 1998; Thomaz, 2002). Among the factors that elicit macrophyte development in reservoirs, we can mention stable water levels, permanent shallow areas, gentle slopes, increased water transparency and nutrient availability (e.g., Bini et al., 1999; Bini \& Thomaz, 2005; Pierini \& Thomaz, 2009; Barbosa et al., 2014; Silva et al., 2014). Consequently, populations of submerged and emergent plants, in particular, have experienced significant development in Neotropical reservoirs (Cavenaghi et al., 2003; Martins et al., 2008; Pitelli et al., 2008). These plants play an important role in the structure and functioning of aquatic ecosystems, providing subsidies for food webs, habitat structure and other ecosystem functions (Carpenter \& Lodge, 1986; Engelhardt \& Ritchie, 2001; Scheffer \& Jeppesen, 2007; Smith, 2011). On the other hand, excessive colonization can disturb human activities by affecting multiple uses of freshwater resources (Boyd, 1971; Pompêo, 2008).
Currently, dams regulate the flow regime of many large and small rivers in Brazil. Impoundments became regular features in the landscape (Agostinho et al., 2016), creating conditions for the development of aquatic macrophytes. This scenario is common in the Paraná River Basin (Southern Brazil), but large impoundments are also present in the Amazon Basin. The main channel of the Tocantins River, for example, is regulated by several large dams (Agostinho et al., 2009; Araújo et al., 2013), and colonization of macrophytes have been reported in reservoirs (Petrere Junior, 1996; De Filippo, 2003; Bianchini Junior et al., 2010). The large and shallow impoundment created by Lajeado Dam (UHE Luís Eduardo Magalhães hydropower plant), middle Tocantins, has favored the expansion of submerged and emergent plants. Few studies have been conducted to date, but they revealed general patterns of richness, composition and abundance (Bianchini Junior et al., 2010; Lolis $\&$ Thomaz, 2011), or the population response of Ludwigia sedoides to some environmental factors (Barbosa et al., 2014). No study, however, has investigated diversity patterns at small spatial scales, particularly the response of plants to depth gradients along the littoral zone.

In this sense, the present study investigated macrophyte assemblage structure in the littoral zone of Lajeado Reservoir, Tocantins River. Our main aim was to characterize plant diversity in shallow habitats, analyzing spatial variations in species richness, composition, occurrence and coverage along depth gradients. We investigated trends among different macrophyte life forms, and characterized the environmental gradient in respect to some morphometric attributes (distance from shores, depth and slope).

\section{Material and Methods}

\subsection{Study area}

The Tocantins River is a major tributary of the Amazon River Basin. It runs northward ca. $2.700 \mathrm{~km}$ from central Brazil to the Marajó Bay (State of Pará), where it joins the Amazon River. 
Upper and middle reaches are covered by savanna vegetation (Cerrado Domain), while rainforests dominate lower segments. At present, the mainstem of the Tocantins River is regulated by 7 large dams, which created impoundments with different areas and lengths (Pelicice et al., 2015).

Lajeado Hydropower Dam was completed in February 2002 and formed a large reservoir of
$630 \mathrm{Km}^{2}$ in the Middle Tocantins River Basin (State of Tocantins). Climate is tropical seasonal, with well-defined rainy (November to April) and dry periods (May to September). The study took place in the municipality of Porto Nacional (TO), located in the upper reach of the impoundment (Figure 1). The region is characterized by extensive shore development, shallow depths (usually $<100 \mathrm{~cm}$ ),

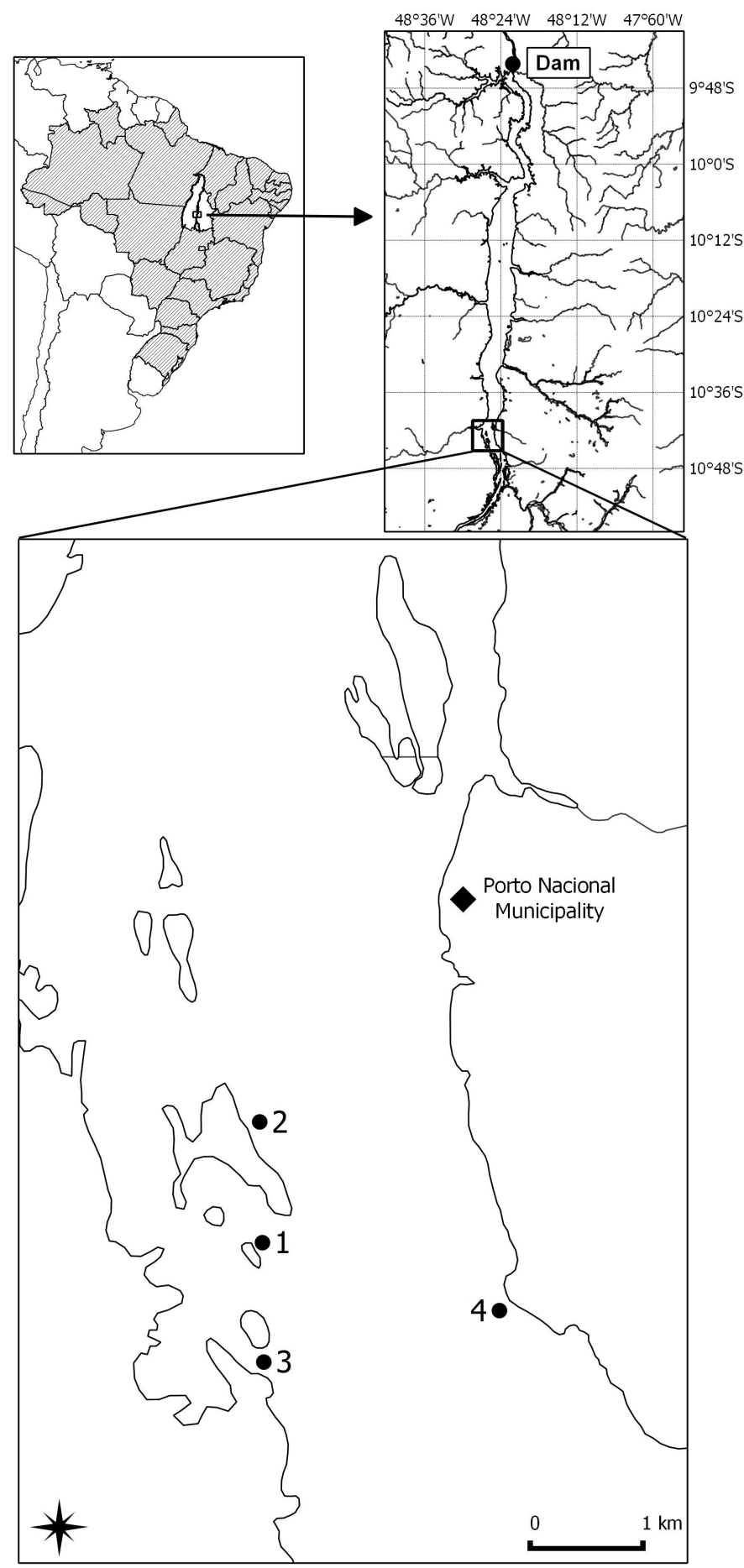

Figure 1. Distribution of sampled sites (1-4) in the upper portion of Lajeado Reservoir, Tocantins River, Brazil. 
high underwater luminosity (Secchi $>150 \mathrm{~cm}$ ), sediment enriched with organic matter, and several localities protected from wind and wave action. These conditions have favored aquatic macrophytes, and about 50 species have been recorded in this reservoir (Bianchini Junior et al., 2010; Lolis \& Thomaz, 2011; Barbosa et al., 2014).

\subsection{Data sampling}

Data sampling occurred at the end of the dry season, between September and October 2014, when macrophyte development is more pronounced (Figure 2). We selected four sites (Figure 1), covering both margins and different environmental conditions, i.e., sheltered and exposed. Sheltered areas are located in the inner part of islands and bays (Sites 1 and 3), while exposed areas are adjacent to the central axis of the reservoir (Sites 2 e 4), subjected to the action of wind and waves.

In each site, we established transects perpendicular to the shoreline, in order to represent a depth gradient. Each transect was $25 \mathrm{~m}$ long, divided in 3 sections: $\mathrm{A}, \mathrm{B}$ and $\mathrm{C}(5 \times 5 \mathrm{~m}$ plots $)$. The first section (A) was close to the shoreline, and the others $(\mathrm{B}, \mathrm{C})$ were spaced at $5 \mathrm{~m}$ intervals. In some cases, the first section was not adjacent to the water-land transition due to the presence of dense mats of terrestrial and amphibian vegetation (i.e. grasses), in addition to dense stands of Oxycarium cubense. In each site we sampled 5 to 10 transects, spaced at 50 to $100 \mathrm{~m}$ intervals.

We investigated only euhydrophytes (i.e. aquatic plants). At each plot, we estimated visually the surface area covered by macrophytes. The plot was divided in 4 equal quadrants, assigning a percentage cover to each species ( 0 to $25 \%$ for each quadrant; $5 \%$ intervals); next, the four estimates were summed. Species with coverage below $5 \%$ were assigned as $1 \%$. Subsequently, a rake was used to remove and collect all plants in the plot. Macrophyte species were identified according to Pott \& Pott (2000); and, when necessary, plants were sent to the Laboratory of Plant Taxonomy (Laboratório de Taxonomia Vegetal, Neamb, Universidade Federal do Tocantins, Brazil) to confirm identification. Species were grouped into life forms (rooted submerged, free submerged, emergent, free floating and epiphytic), following Sculthorpe (1967), Pott \& Pott (2000) and Thomaz \& Esteves (2011). Voucher specimens are deposited in the Herbarium of the Laboratory of Plant Taxonomy (code HTO in the Index Herbariorum, New York Botanical Garden).
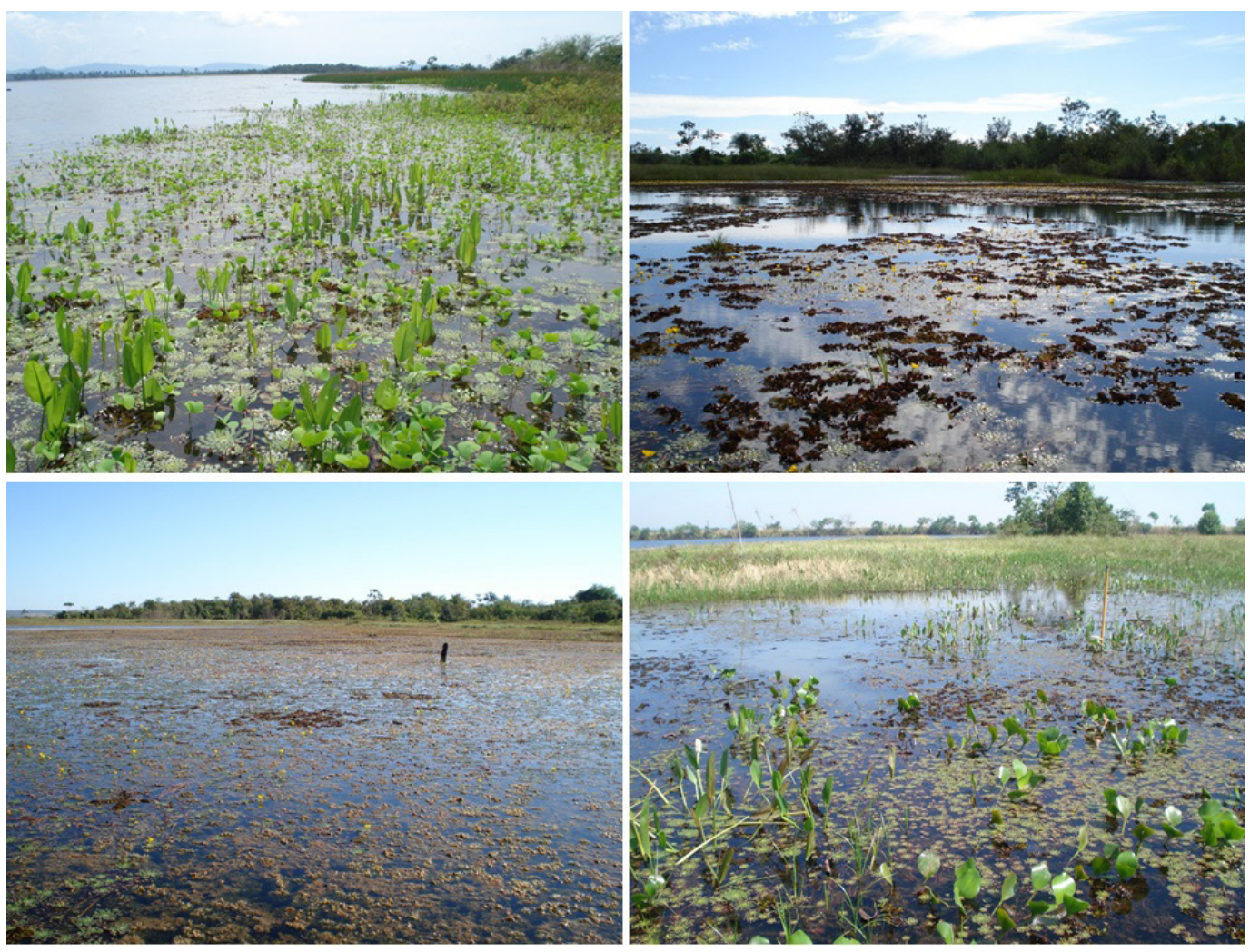

Figure 2. Shallow habitats in the Lajeado Reservoir, Tocantins River, where aquatic macrophytes have developed extensive multi-specific stands along the littoral zone. 
Three morphometric variables were measured in each plot: slope (margin declivity), mean depth and distance from shoreline. The slope was calculated using three equidistant ( $2.5 \mathrm{~m}$ intervals) measures of depth, taken from each side of the plot (perpendicular to the margin, 6 values in total). A ruler was used to measure each depth sample $(\mathrm{cm})$. The slope of each plot $(\mathrm{cm} / \mathrm{m})$ was then obtained through linear regression between depth $(\mathrm{m})$ and distance $(\mathrm{m})$, fitting a linear equation to obtain the b-coefficient (slope). We also used these six depth measures to calculate the mean depth of each plot. Finally, the distance between the plot and the nearest shoreline was estimated visually $(\mathrm{m})$.

\subsection{Data analysis}

We considered species richness, composition and abundance (\% coverage) to investigate patterns of macrophyte diversity along depth gradients (transect sections). Analyses were carried out considering all taxa, dominant life forms (emergent and submerged; rooted and free combined), and the most abundant species. To characterize the environmental gradient, we considered the three morphometric variables: slope, depth and distance from the shoreline.
We calculated mean values and standard errors among sections (A, B, C))) to describe spatial patterns (biotic and abiotic) along the gradient. Statistical differences $(\mathrm{p}<0.05)$ among sections were tested with non-parametric Analysis of Variance (Kruskal-Walis), using the Mann-Whitney test to compare groups. A Nonmetric Multidimensional Scaling (NMDS) was applied to investigate variation in species composition among sections, based on Sorensen similarity (presence/absence matrix). All statistical analyses were conducted in the software Past 2.17c (Hammer et al., 2001).

\section{Results}

In the four sites, we sampled 82 plots distributed along 33 independent transects: 33 plots in section-A, 25 in section-B and 24 in section-C. There was significant variation in environmental conditions along the gradient. Distance from the shoreline and depth naturally increased along the transect; slope showed no difference among sections (Figure 3).

In total, we recorded 18 taxa of aquatic macrophytes, belonging to 9 families and 4 life forms (Table 1). Total species richness was similar among sites: Site- $1=14$ species; Site- $2=14$;
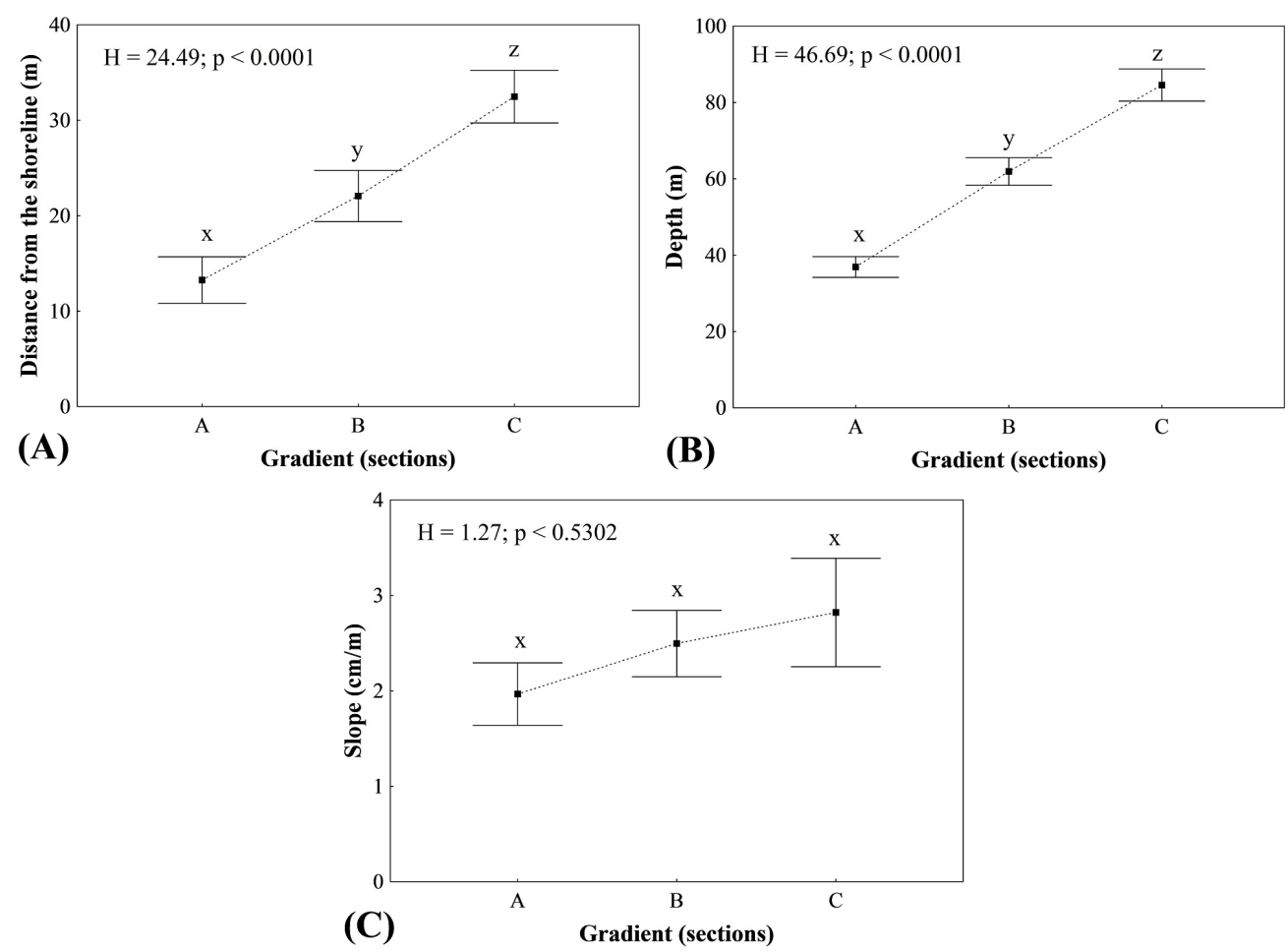

Figure 3. Variation in morphometric variables (distance from the shoreline $(\mathrm{A})$, depth $(\mathrm{B})$ and slope $(\mathrm{C})$ ) along the depth gradient (sections A, B and C). Dots are mean values and bars represent the standard error. Statistical differences among sections were tested with non-parametric ANOVA (Kruskal-Wallis, H) and Mann-Whitney pairwise comparison (different letters). 
Site-3 = 15; Site- $4=13$. Submerged (rooted and free) and emergent life forms comprised 9 and 7 taxa, respectively, while epiphyte and free-floating life forms had a single species each (Table 1). Oxycarium cubense was the only species assigned to two life forms, because it is epiphytic during early life stages, but emergent during mature stages (Pott $\&$ Pott, 2000).

Considering depth gradients, we recorded 18 taxa in section-A, 13 in section-B and 10 in section-C. Najas microcarpa, Echinodorus tenellus and Chara sp. were the more frequent species along the depth gradient. (Table 1). Species with lower occurrence were Echinodorus paniculatus, Fuirena umbellata and Eichhornia azurea (Table 1). Submerged taxa were more common along the depth gradient, especially in section-A. Epiphytes and free-floating taxa were rare (abundance and occurrence) in all sections.
Plot species richness (all taxa, emergent and submerged) decreased along the gradient, where section-A had the highest values (Figure 4A). At each section, we recorded more submerged than emergent species (Figure 4B). The NMDS revealed that composition varied considerably among plots (Figure 5). However, along axis 1, section-A plots tended to separate from other sections, while plots in sections $\mathrm{B}$ and $\mathrm{C}$ were more overlapped.

The most abundant species (\% coverage) were N. microcarpa, E. tenellus, Chara sp., L. sedoides, Pontederia parviflora and S. auriculata (Table 1). Some taxa presented no significant variation among sections, but occurrence decreased along the depth gradient (Table 1). Ludwigia sedoides, P. parviflora and $S$. auriculata were more abundant in section-A, while $N$. microcarpa were more abundant in sections $\mathrm{B}$ and $\mathrm{C}$ (Figure 6).

Table 1. Aquatic macrophytes recorded along depth gradients in Lajeado Reservoir, their respective life forms, mean abundance (\% Cover and standard deviation), and frequency of occurrence (\% FO) in the sections A, B, C. Life Forms: $\mathrm{EME}=$ emergent; R-SUB = rooted submerged; F-SUB = free submerged $; \mathrm{EPI}=$ epiphytic; F-FLO = free-floating.

\begin{tabular}{|c|c|c|c|c|c|}
\hline \multirow{2}{*}{ Taxa } & \multirow{2}{*}{ Life forms } & \multirow{2}{*}{$\%$ Cover (SD) } & \multicolumn{3}{|c|}{$\%$ FO } \\
\hline & & & A & B & C \\
\hline \multicolumn{6}{|l|}{ ALISMATACEAE } \\
\hline Echinodorus paniculatus Micheli & EME & $0.01(0.11)$ & 3.0 & 0 & 0 \\
\hline Echinodorus tenellus (Mart.) Buch. & R-SUB & $12.60(22.85)$ & 84.8 & 76.0 & 58.3 \\
\hline \multicolumn{6}{|l|}{ CHARACEAE } \\
\hline Chara sp. & R-SUB & $10.39(21.82)$ & 84.8 & 68.0 & 58.3 \\
\hline Nitella sp. & R-SUB & $1.12(4.11)$ & 39.4 & 32.0 & 25.0 \\
\hline \multicolumn{6}{|l|}{ CYPERACEAE } \\
\hline Bulbostylis capillaris (L.) C.B. Clarke & R-SUB & $3.02(0.72)$ & 21.2 & 8.0 & 0 \\
\hline $\begin{array}{l}\text { Eleocharis interstincta (Vahl) Roem. } \\
\text { \& Schult. }\end{array}$ & EME & $1.78(8.21)$ & 18.2 & 0 & 0 \\
\hline Fuirena umbellata Rottb. & EME & $0.04(0.19)$ & 9.1 & 0 & 0 \\
\hline $\begin{array}{l}\text { Oxycaryum cubense (Poepp. \& } \\
\text { Kunth) Lye }\end{array}$ & $\begin{array}{l}\text { EPI (early) } \\
\text { EME (mature) }\end{array}$ & $1.18(3.76)$ & 42.4 & 8.0 & 0 \\
\hline \multicolumn{6}{|c|}{ LENTIBULARIACEAE } \\
\hline Utricularia foliosa L. & F-SUB & $0.17(0.80)$ & 12.1 & 8.0 & 0 \\
\hline Utricularia gibba L. & F-SUB & $0.23(0.42)$ & 36.4 & 20.0 & 8.3 \\
\hline \multicolumn{6}{|l|}{ NAJADACEAE } \\
\hline $\begin{array}{l}\text { Najas guadalupensis (Spreng.) } \\
\text { Magnus }\end{array}$ & R-SUB & $0.51(2.46)$ & 15.1 & 16.0 & 20.8 \\
\hline Najas microcarpa K. Schum. & R-SUB & $35.48(40.28)$ & 75.7 & 88.0 & 100 \\
\hline \multicolumn{6}{|l|}{ ONAGRACEAE } \\
\hline Ludwigia sedoides (H.B.K.) Hara & EME & $6.28(15.63)$ & 63.6 & 36.0 & 25.0 \\
\hline \multicolumn{6}{|l|}{ POACEAE } \\
\hline Unidentified & EME & $0.01(0.11)$ & 3.0 & 0 & 0 \\
\hline \multicolumn{6}{|l|}{ PONTEDERIACEAE } \\
\hline Eichhornia azurea (Sw.) Kunth. & EME & $0.55(2.72)$ & 12.1 & 0 & 0 \\
\hline Hydrothrix gardneri Hook.f. & R-SUB & $0.56(1.61)$ & 33.3 & 12.0 & 12.5 \\
\hline Pontederia parviflora Alexander & EME & $4.28(12.25)$ & 60.6 & 8.0 & 16.7 \\
\hline \multicolumn{6}{|l|}{ SALVINIACEAE } \\
\hline Salvinia auriculata Aubl. & F-FLO & $3.60(8.39)$ & 81.8 & 16.0 & 4.2 \\
\hline
\end{tabular}



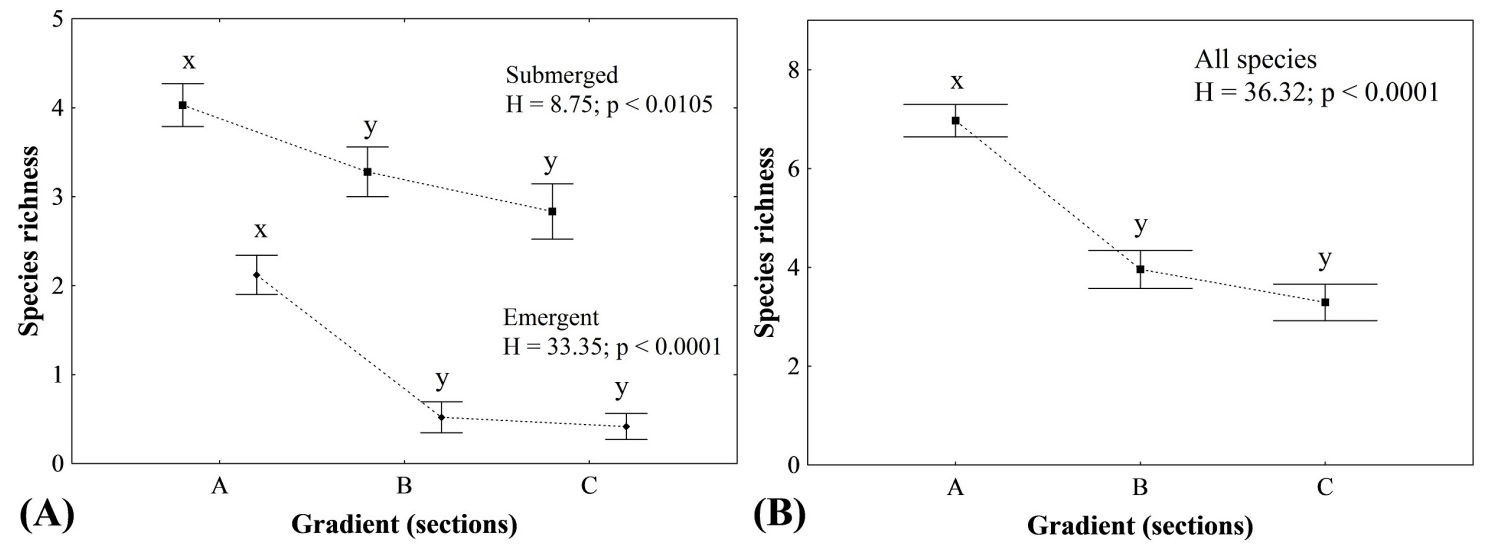

Figure 4. Variation in species richness (all species (A) and different life forms(B)) along the depth gradient (sections A, B and C). Dots are mean values and bars represent the standard error. Statistical differences among sections were tested with non-parametric ANOVA (Kruskal-Wallis, H) and Mann-Whitney pairwise comparison (different letters).

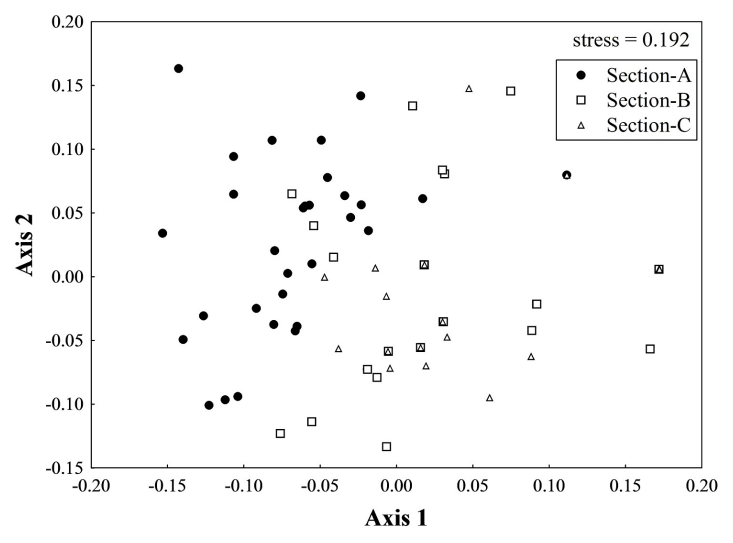

Figure 5. Non-metric Multidimensional Scaling (NMDS) showing differences in plot composition along the depth gradient (sections A, B and C).

\section{Discussion}

The present study revealed that small-scale gradients affect the structure and distribution of aquatic plants in Lajeado Reservoir, Tocantins River. We observed significant variation in species richness, composition and abundance along depth gradients in the littoral zone. The area close to the shoreline (section-A) showed greater diversity; in fact, all taxa $(S=18)$ were recorded in this section, while adjacent habitats (B and C) had lower species richness, abundance and occurrence. This is a common pattern in shallow lentic ecosystems, where many species are restricted to the first few meters of the littoral zone (Ferreira et al., 2010). Habitats near the water-land transition (e.g. section-A) usually favor the massive colonization of emergent species. Habitats offshore, on the other hand, tend to have greater depth and slope, affecting light availability and sediment type (Thomaz, 2002; Ferreira et al., 2010). Therefore, macrophyte life forms tend to colonize the littoral zone according to their niche demands (Pott \& Pott, 2003; Ferreira et al., 2010), with amphibious and emergent dominating very shallow habitats, and submerged rooted species developing dense mats in adjacent sites (Thomaz \& Esteves, 2011). Our results confirm these biotic gradients in Lajeado Reservoir, but some species colonized the whole gradient, probably because the littoral zone in this reservoir favor the development of aquatic plants, i.e. extensive shore development, shallow depths $(<2 \mathrm{~m})$, gentle slopes, stable water level, high water transparency and sites protected by wind/wave action (Lolis \& Thomaz, 2011; Barbosa et al., 2014).

Submerged macrophyte species showed, in particular, high frequency, cover and richness along the entire gradient. The most abundant species were N. microcarpa, E. tenellus and Chara sp., especially the former, which is the dominant species in the reservoir. Water transparency is probably a key ecological factor behind these patterns since radiation is a limiting factor for submerged species. The Tocantins River has a clear water type, and Lajeado Reservoir is oligotrophic, with high underwater radiation (Lolis \& Thomaz, 2011). When transparency is not a limiting factor, submerged species tend to dominate in both shallow and deep waters (Bini et al., 1999; Smith et al., 2014). For example, Pierini \& Thomaz (2009) registered Egeria densa stands, a species similar to N. microcarpa, at depths ranging from 0.2 to $6 \mathrm{~m}$. Similarly, Utsumi et al. (2011) recorded submerged species at depths above $4 \mathrm{~m}$. In Lajeado Reservoir, 

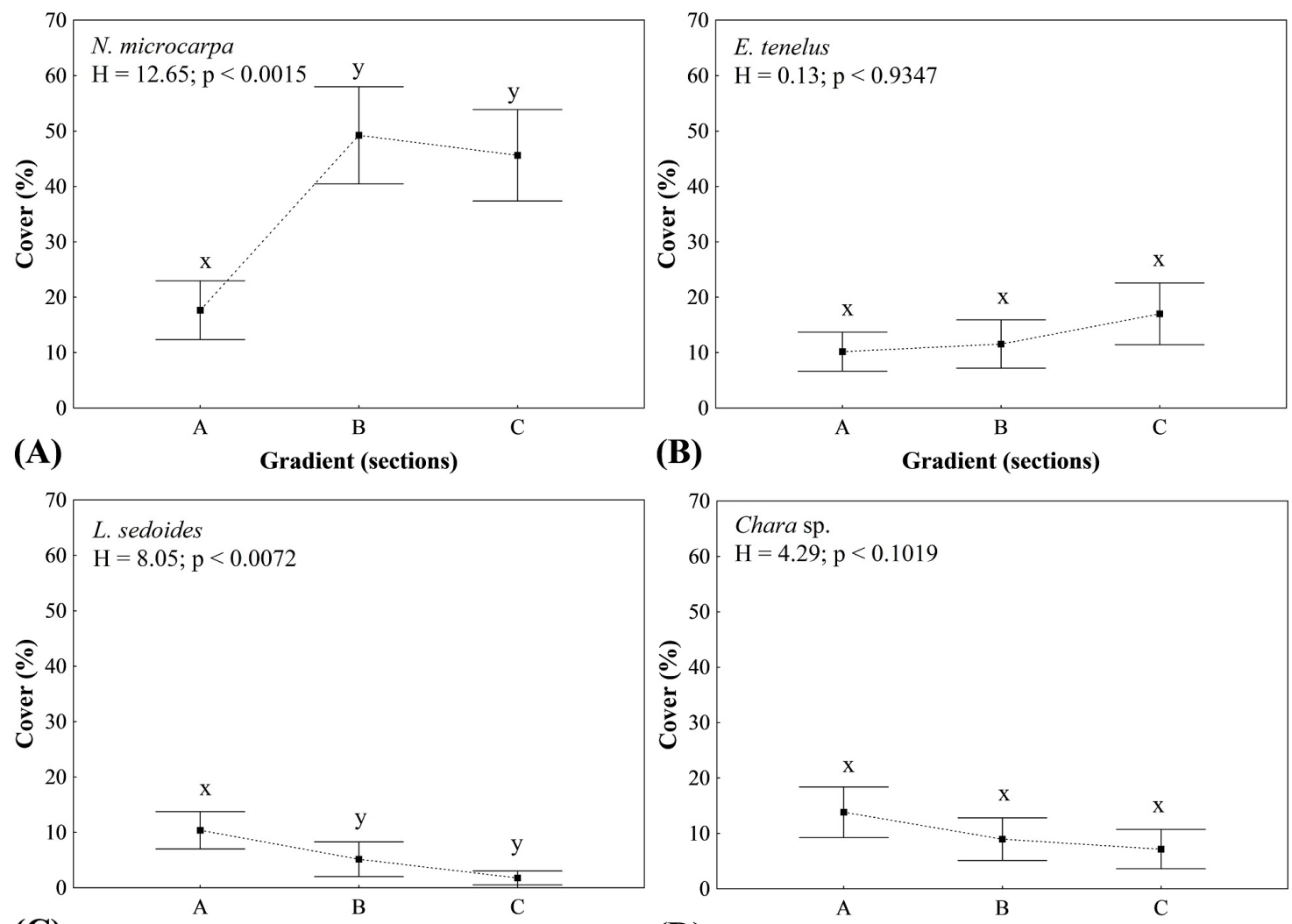

(B)

Gradient (sections)

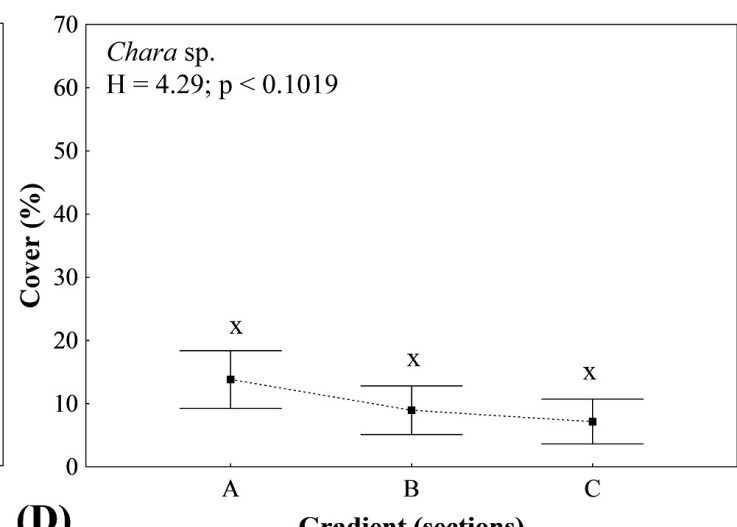

(C) Gradient (sections)

(D)

Gradient (sections)

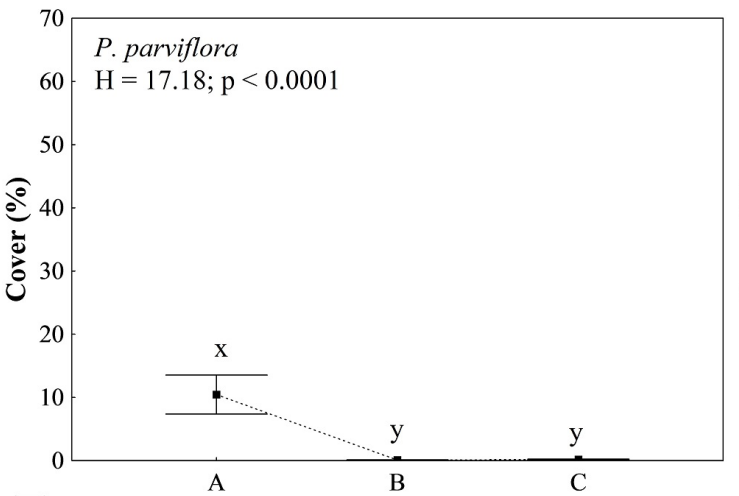

(E)

Gradient (sections)

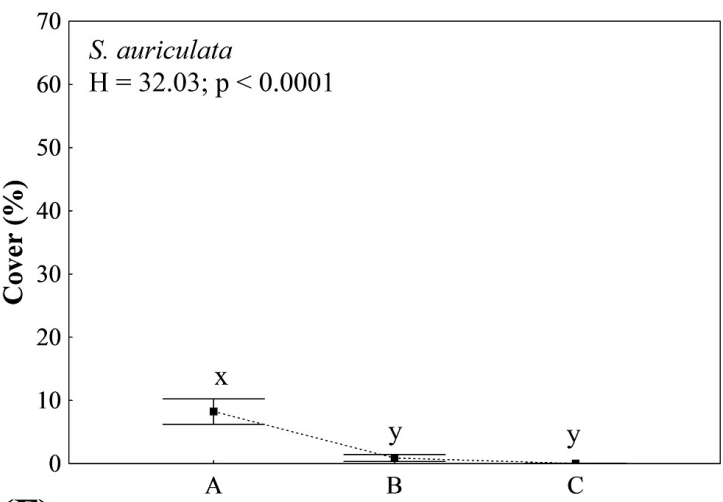

(F)

Gradient (sections)

Figure 6. Variation in the abundance (\% cover) of main species (A-F) along the depth gradient (sections A, B and C). Dots are mean values and bars represent the standard error. Statistical differences among sections were tested with non-parametric ANOVA (Kruskal-Wallis, H) and Mann-Whitney pairwise comparison (different letters).

species richness declined along the gradient, but some submerged plants showed high occurrence and abundance offshore; $N$. microcarpa, in particular, was the main species in sections $\mathrm{B}$ and $\mathrm{C}$. This pattern is probably related to the disturbance caused by wave action in very shallow habitats, which negatively affects plant anchoring. We highlight that our transects did not include deep habitats (maximum depth $=1.39 \mathrm{~m}$ ), since the littoral zone extends through dozens of meters, creating a wide area to be colonized.
Emergent macrophytes were the second group in terms of richness and cover. They formed multi-specific stands in very shallow areas, with decreasing diversity along the depth gradient. Some species were common and abundant in section-A (L. sedoides and P. parviflora), probably due to low depths and gentle slopes. Depth is a main factor, since many emergent species (e.g., P. parviflora, $E$. intersticta, E. paniculatus) have short stems and leaves, demanding shallow environments to expose their photosynthetic organs to insolation, and 
flowers to pollinizers. In these shallow habitats, the emergent taxa have competitive advantage over submerged and floating species, because their leaves remain exposed to intense radiation while their root systems uptake nutrients directly from the sediment. Slope is another important factor for emergent macrophytes, because it directly affects sediment grain size, chemical composition and stability; these conditions affect negatively plant anchoring and growth (Bornette \& Puijalon, 2011). Barbosa et al. (2014) observed that slope, together with fetch and depth, are the main factors regulating the coverage and distribution of L. sedoides in Lajeado Reservoir. The present study, however, included sites with gentle slopes, so this variable may have a secondary role influencing the distribution of emergent macrophytes. Therefore, distance from the shoreline and depth must work as better predictors.

The free-floating life form was rare in the studied sites, represented by a single species, $S$. auriculata. This plant was more common in habitats close to the shore, where free-floating macrophytes passively drift and accumulate in response to wind action. It is worth noting that morphometric variables considered in this survey, such as depth and slope, have low predictive value, once floating plants are more affected by wind action, currents, nutrients and fetch (Camargo et al., 2003; Marques-Silva $\&$ Thomaz, 2009). They usually proliferate in sheltered sites, lentic and eutrophic systems (Bini et al., 1999; Thomaz \& Esteves, 2011; Bottino et al., 2013). They may also thrive among roots and stems of emergent plants in the littoral zone (Marques-Silva \& Thomaz, 2009; Thomaz \& Esteves, 2011), as commonly observed in Lajeado Reservoir. In addition, free-floating plants find favorable conditions in young impoundments (Petrere Junior, 1996; Thomaz \& Bini 1998; De Filippo, 2003), when nutrients are released from submerged organic matter. Extensive stands of floating macrophytes were recorded during the early years of Lajeado (Bianchini Junior et al., 2010), but the current oligotrophic status probably controls the development of this life form. This condition, however, may change in the coming years, since the basin is experiencing considerable expansion of agribusiness, aquaculture and urban activities, which can accelerate eutrophication processes. We also highlight the expansion of $O$. cubense mats, an epiphytic species that colonize $S$. auriculata and other floating plants. When it grows, $O$. cubense develops dense mats in the land-water transition zone. Although our sampling design did not cover this habitat (i.e., we focused on euhydrophytes), these mats are now common in Lajeado Reservoir. Future studies must devote effort to measure their biomass and distribution, mainly because they negatively affect human activities (e.g., access to margins and navigation).

During its first years, aquatic macrophytes formed stable stands but occupied a small area of Lajeado Reservoir (Bianchini Junior et al., 2010). However, stands have expanded in sheltered areas during the last 5 years, mainly $N$. microcarpa, which have developed large stands. Such expansion emphasizes the need to understand the ecological factors that regulate plant diversity in this tropical impoundment. Considering that plant diversity responds to environmental gradients, local factors must play a significant role at small spatial scales as noted by other studies (Capers et al., 2010). Morphometric variables (distance from the shoreline, depth and slope), in particular, may have high predictive value for species richness, occurrence and coverage of submerged and emergent species (e.g., Barbosa et al., 2014). To improve predictive and explanatory power, future research must investigate other variables at small spatial scales, such as nutrient availability, limnological conditions, fetch and competition (Camargo et al., 2003; Lacoul \& Freedman, 2006; Bornette \& Puijalon, 2011).

\section{Acknowledgements}

We thank colleagues from Universidade Federal do Tocantins (Brazil) for helping with field sampling (Carla Freitas and Marco Aurélio Santos) and species identification (Solange Lolis and Rodney Haulien). We also thank Núcleo de Estudos Ambientais and Universidade Federal do Tocantins for providing the infrastructure. CNPq provided a research grant to Fernando Mayer Pelicice.

\section{References}

AGOSTINHO, A.A., GOMES, L.C. and PELICICE, F.M. Ecologia e manejo de recursos pesqueiros em reservatórios do Brasil. Maringá: UDUEM, 2007.

AGOSTINHO, A.A., GOMES, L.C., SANTOS, N.C.L., ORTEGA, J.C.G. and PELICICE, F.M. Fish assemblages in Neotropical reservoirs: colonization patterns, impacts and management. Fisheries Research, 2016, 173, 26-36. http://dx.doi. org/10.1016/j.fishres.2015.04.006.

AGOSTINHO, A.A., PELICICE, F.M. and GOMES, L.C. Dams and the fish fauna of the Neotropical 
region: impacts and management related to diversity and fisheries. Brazilian Journal of Biology = Revista Brasileira de Biologia, 2008, 68(4 Suppl), 1119-1132. http://dx.doi.org/10.1590/S151969842008000500019. PMid:19197482.

AGOSTINHO, C.S., AKAMA, A. and LUCINDA, P.H.F. Inserção da UHE Peixe Angical na bacia Araguaia-Tocantins e metodologias de amostragem. In: C.S. Agostinho, F.M. Pelicice and E.E. Marques, eds. Reservatório de Peixe Angical: bases ecológicas para o manejo da ictiofauna. São Carlos: RiMa, 2009, pp. 5-13

ARAÚJO, E.S., MARQUES, E.E., FREITAS, I.S., NEUBERGER, A.L., FERNANDES, R. and PELICICE, F.M. Changes in distance decay relationships after river regulation: similarity among fish assemblages in a large Amazonian river. Ecology Freshwater Fish, 2013, 22(4), 543-552. http://dx.doi. org/10.1111/eff.12054.

BARBOSA, M.V.M., KOBAYASHI, J.T. and PELICICE, F.M. Morphometric and biotic variables as potential predictors of Ludwigia sedoides (Humb. \& Bonpl.) Hara in a large Amazonian reservoir. Annales de Limnologie-International Journal of Limnology, 2014, 50(2), 163-171. http://dx.doi. org/10.1051/limn/2014009.

BIANCHINI JUNIOR, I., CUNHA-SANTINO, M.B., FUSHITA, A.T., ALMEIDA, D.A.A. and MAIA, A. Monitoramento das macrófitas aquáticas do reservatório da Usina Hidrelétrica Luís Eduardo Magalhães (Estado de Tocantins, Brasil). Augm Domus, 2010, 2, 38-48.

BINI, L. and THOMAZ, S.M. Prediction of Egeria najas and Egeria densa occurrence in a large subtropical reservoir (Itaipu Reservoir, Brazil-Paraguay). Aquatic Botany, 2005, 83(3), 227-238. http://dx.doi. org/10.1016/j.aquabot.2005.06.010.

BINI, L.M., THOMAZ, S.M., MURPHY, K.J. and CAMARGO, A.F.M. Aquatic macrophyte distribution in relation to water and sediment conditions in the Itaipu Reservoir, Brazil. Hydrobiologia, 1999, 415(0), 147-154. http://dx.doi. org/10.1023/A:1003856629837.

BORNETTE, G. and PUIJALON, S. Response of aquatic plants to abiotic factors: a review. Aquatic Sciences, 2011, 73(1), 1-14. http://dx.doi. org/10.1007/s00027-010-0162-7.

BOTTINO, F., CALIJURI, M. and MURPHY, K.J. Temporal and spatial variation of limnological varibles and biomass of different macrophyte species in a Neotropical reservoir (São Paulo - Brazil). Acta Limnologica Brasiliensia, 2013, 25(4), 387-397. http://dx.doi.org/10.1590/S2179975X2013000400004.

BOYD, C.E. The limnological role of aquatic macrophytes and their relationship to reservoir management. In: Hall, G.E., ed. Reservoir fisheries and limnology.
Washington: American Fisheries Society, 1971, pp.153-166.

CAMARGO, A.F.M., PEZZATO, M.M. and HENRYSILVA, G.G. Fatores limitantes à produção primária de macrófitas aquáticas. In: S.M. THOMAZ and L.M. BINI, eds. Ecologia e manejo de macrófitas aquáticas. Maringá: EDUEM, 2003, pp. 59-83.

CAPERS, R.S., SELSKY, R. and BUGBEE, G.J. The relative importance of local conditions and regional processes in structuring aquatic plant communities. Freshwater Biology, 2010, 55(5), 952-966. http:// dx.doi.org/10.1111/j.1365-2427.2009.02328.x.

CARPENTER, S.R. and LODGE, D.M. Effects of submersed macrophytes on ecosystem process. Aquatic Botany, 1986, 26(3-4), 341-370. http:// dx.doi.org/10.1016/0304-3770(86)90031-8.

CAVENAGHI, A.L., VELINI, E.D., GALO, M.L.B.T., CARVALHO, F.T., NEGRISOLI, E., TRINDADE, M.L.B. and SIMIONATO, J.L.A. Caracterização da qualidade de agua e sedimento relacionados com a ocorrência de plantas aquáticas em cinco reservatórios da bacia do Rio Tiete. Planta Daninha, 2003, 21(N. esp.), 43-52. http://dx.doi.org/10.1590/S010083582003000400007.

DE FILIPPO, R. Colonização e regressão da comunidade de macrófitas aquáticas no reservatório da UHE Serra da Mesa Goiás. In: S.M. THOMAZ and M. BINI, orgs. Ecologia e manejo de macrófitas aquáticas. Maringá: EDUEM, 2003, pp. 281-298.

ENGELHARDT, K.A.M. and RITCHIE, M.E. Effects of macrophyte species richness on wetland ecosystem functioning and services. Nature, 2001, 411(6838), 687-689. http://dx.doi.org/10.1038/35079573. PMid:11395769.

FERREIRA, F.A., MORMUL, R.P., PEDRALLI, G., POTT, V.J. and POTT, A. Estrutura da comunidade de macrófitas aquáticas em três lagoas do Parque Estadual do Rio Doce, Minas Gerais, Brasil. Hoehnea, 2010, 37(1), 43-52. http://dx.doi.org/10.1590/ S2236-89062010000100003.

GALO, M.L.B.T., VELINI, E.D., TRINDADE, M.L.B. and SANTOS, S.C.A. Usos do sensoriamento remoto orbital no monitoramento da dispersão de macrófitas nos reservatórios do complexo Tietê. Planta Daninha, 2002, 20(N. esp.), 7-20. http://dx.doi.org/10.1590/ S0100-83582002000400002.

HAMMER, O., HARPER, D.A.T. and RIAN, P.D. Past: Palaeonthological statistics software package for education and data analysis. Version. 1.37 [online]. 2001 [viewed 19 Dec. 2018]. Available from: http:// palaeo-electronica.org/2001_1/past/issue1_01.htm

LACOUL, P. and FREEDMAN, B. Relationships between aquatic plants and environmental factors along a steep Himalayan altitudinal gradient. Aquatic Botany, 2006, 84(1), 3-16. http://dx.doi. org/10.1016/j.aquabot.2005.06.011.

LOLIS, S.F. and THOMAZ, S.M. Monitoramento da composição específica da comunidade de macrófitas 
aquáticas no reservatório Luís Eduardo Magalhães. Planta Daninha, 2011, 29(2), 247-258. http:// dx.doi.org/10.1590/S0100-83582011000200002.

MARQUES-SILVA, G.G. and THOMAZ, S.M. Biological interactions in the co-occurrence of Eichhornia azurea and free-floating macrophytes. Acta Scientiarum. Biological Sciences, 2009, 31(4), 355-361. http://dx.doi.org/10.4025/actascibiolsci. v31i4.5577.

MARTINS, D., COSTA, N.V., TERRA, M.A. and MARCHI, S.R. Characterization of the aquatic plant communities of 18 reservoirs of five watersheds in Sao Paulo, Brazil. Planta Daninha, 2008, 26(1), 17-32. http://dx.doi.org/10.1590/S010083582008000100003.

MURPHY, K.J. Predizendo alteraçôes em ecossistemas aquáticos continentais e áreas alagáveis: o potencial de sistemas bioindicadores funcionais utilizando macrófitas aquáticas. Boletim da Sociedade Brasileira de Limnologia, 2000, 27, 7-9.

PELICICE, F.M., POMPEU, P.S. and AGOSTINHO, A.A. Large reservoirs as ecological barriers to downstream movements of Neotropical migratory fish. Fish and Fisheries, 2015, 16(4), 697-715. http:// dx.doi.org/10.1111/faf.12089.

PETRERE JUNIOR, M. Fisheries in large tropical reservoirs in South America. Lakes and Reservoirs: Research and Management, 1996, 2(2), 111-133. http://dx.doi.org/10.1111/j.1440-1770.1996. tb00054.x.

PIERINI, S.A. and THOMAZ, S.M. Effects of limnological and morphometric factors upon $\mathrm{Zmin}$, Zmax and width of Egeria spp. stands in a tropical reservoir. Brazilian Archives of Biology and Technology, 2009, 52(4), 387-396. http://dx.doi.org/10.1590/ S1516-89132009000200016.

PITELLI, R.L.C.M., TOFFANELI, C.M., VIEIRA, E.A., PITELLI, R.A. and VELINI, E.D. Dinâmica da comunidade de macrófitas aquáticas no reservatório de Santana, RJ. Planta Daninha, 2008, 26(3), 473-480. http://dx.doi.org/10.1590/S010083582008000300001 .

POFF, N.L., ALLAN, J.D., BAIN, M.B., KARR, J.R., PRESTEGAARD, K.L., RICHTER, B.D., SPARKS, R.E. and STROMBERG, J.C. The natural flow regime: a paradigm for river conservation and restoration. Bioscience, 1997, 47(11), 769-784. http://dx.doi.org/10.2307/1313099.

POMPÊ, M. Monitoramento e manejo de macrófitas aquáticas. Oecologia Brasiliensis, 2008, 12(3), 406424.

POTT, V.J. and POTT, A. Dinâmica da vegetação aquática do Pantanal. In: S.M. Thomaz and L.M. Bini, eds. Ecologia e manejo de macrófitas aquáticas. Maringá: EDUEM, 2003, pp. 145-162.

POTT, V.J. and POTT, A. Plantas aquáticas do Pantanal. Corumbá: EMBRAPA, 2000, 353 p.
SCHEFFER, M. and JEPPESEN, E. Regime shifts in shallow lakes. Ecosystems (New York, N.Y.), 2007, 10(1), 1-3. http://dx.doi.org/10.1007/s10021-0069002-y.

SCULTHORPE, C.D. The biology of aquatic vascular plants. New York: St. Martin's, 1967, 610 p.

SILVA, S.C.A., CERVI, A.C., BONA, C. and PADIAL, A.A. Aquatic macrophyte community varies in urban reservoirs with different degrees of eutrophication. Acta Limnologica Brasiliensia, 2014, 26(2), 129-142. http://dx.doi.org/10.1590/S2179975 X2014000200004.

SMITH, M.D. The ecological role of climate extremes: current understanding and future prospects. Journal of Ecology, 2011, 99(3), 651-655. http://dx.doi. org/10.1111/j.1365-2745.2011.01833.x.

SMITH, W.S., ESPINDOLA, E.L. and ROCHA, O. Environmental gradient in reservoirs of the medium and low Tietê River: limnological differences through the habitat sequence. Acta Limnologica Brasiliensia, 2014, 26(1), 73-88. http://dx.doi.org/10.1590/ S2179-975X2014000100009.

SOLIMINI, A.G., CARDOSO, A.C. and HEISKANEN, A.S. Indicators and methods for the ecological status assessment under the Water Framework Directive: linkages between chemical and biological quality of surface waters. Luxembourg: European Communities, 2006.

THOMAZ, S.M. and BINI, L.M. Ecologia e manejo de macrófitas aquáticas em reservatórios. Acta Limnologica Brasiliensia, 1998, 10(1), 103-116.

THOMAZ, S.M. and ESTEVES, F.S.E. Comunidade de macrófitas aquáticas. In: F.A.E. Esteves, ed. Fundamentos de limnologia. 3. ed. Rio de Janeiro: Interciência, 2011, pp. 461-518.

THOMAZ, S.M. Fatores ecológicos associados à colonização e ao desenvolvimento de macrófitas aquáticas e desafios de manejo. Planta Daninha, 2002, 20(1), 21-33. http://dx.doi.org/10.1590/ S0100-83582002000400003.

TUNDISI, J.G. and MATSUMURA-TUNDISI, $T$. Integration of research and management in optimizing multiple uses of reservoirs: The experience in South America and Brazilian case studies. Hydrobiologia, 2003, 500(1-3), 231-242. http:// dx.doi.org/10.1023/A:1024617102056.

UTSUMI, A.G., ROTTA, L.H.S., GALO, M.L.B.T and TACHIBANA, V.M. Inferência de macrófitas aquáticas submersas por meio da Geoestatística. In: Simpósio Brasileiro de Sensoriamento Remoto. São José dos Campos: INPE, 2011, pp. 2279-2285.

Received: 11 July 2017 Accepted: 18 December 2018 